九州大学学術情報リポジトリ

Kyushu University Institutional Repository

\title{
Cattle Bedding Waste Used as a Substrate in the Cultivation of Agaricus blazei Murill
}

Pokhrel, Chandra Prasad

Graduate School of Bioresource and Bioenvironment Sciences, Kyushu University

Oga, Shoji

Faculty of Agriculture Kyushu University

https://doi.org/10.5109/9317

出版情報: 九州大学大学院農学研究院紀要. 52 (2)，pp. 295-298，2007-10-29. Faculty of Agriculture, Kyushu University

バージョン：

権利関係 : 


\title{
Cattle Bedding Waste Used as a Substrate in the Cultivation of Agaricus blazei Murill
}

\author{
Chandra Prasad POKHREL ${ }^{1}$ and Shoji OHGA*
}

\author{
Laboratory of Forest Resource Management, Division of Ecosphere Sciences and Management \\ Department of Forest and Forest Products Sciences, Faculty of Agriculture \\ Kyushu University, Fukuoka 811-2415, Japan \\ (Received June 25, 2007 and accepted July 17, 2007)
}

\begin{abstract}
The potential use of beef cattle bedding compost as a substrate for the production of the biomedical mushroom Agaricus blazei Murrill was tested and evaluated on various compost concentrations with fortified supplements. All tested concentrations (100\% with equal supplement), 75, 50 and 25\%) were found to be suitable for mycelial growth and fruit body development. Biological efficiency (BE) ranged from $28.6 \%$ to $70.9 \%$ in the two harvests of mushrooms. Compost with $100 \%$ and $75 \%$ were far superior to all other compost concentrations. The yield was greatest on $100 \%$ and $75 \%$ compost, with BE of $70.9 \%$ and $63.4 \%$, respectively. Compost with $50 \%$ and $25 \%$ yielded significantly less with BE of $45.1 \%$ and $28.6 \%$, respectively. Compost with $75 \%$ influenced faster mycelial extension, earlier spawn run, primordial initiation, earlier fruiting with bigger mushroom size, whereas higher supplement (100\%) achieved a higher yield with smaller mushroom size. Our results showed that beef cattle bedding compost is a potential substrate in A. blazei cultivation; however, compost concentration selection is important to improve biological efficiency and mushroom yield.
\end{abstract}

\section{INTRODUCTION}

Agaricus blazei Murrill, an edible mushroom belonging to the Agaricaceae family, is native to southern Brazil. It is popularly known as "Himematsutake" in Japan. A. blazei Murrill, is an attractive brown mushroom with sparkling gill caps and snow-white stalks, which are often enlarged at the base. It naturally occurs in fields and mountainous regions in warm and humid weather, in soil-rich organic matter associated with mixed wood and grasslands rich in cattle manure. It favors high temperatures and light. This mushroom is the secondary decomposer, which grows on material already partially degraded by microorganisms, and requires fermented compost as a substrate, unlike other primary saprophytes such as Lentinus edodes, Grifola frondosa and Ganoderma lucidum. Cultivation of $A$. blazei is well established and pioneered throughout Japan in indoor cultivation and is the most popular in consumption as well.

At present, A. blazei Murrill is widely used as a medicinal and functional food rather than for its nutritional purposes because of its potent medicinal properties (Kuroiwa et al., 2005). Brazilian mushroom (A. blazei) was reported to possess antitumour and immunomodulating activities (Kawagishi et al., 1998). Its isolated polysaccharides could stimulate lymphocyte T-cells in mice (Mizuno et al., 1998). A. blazei Murill is particularly rich in polysaccharides and has shown particularly strong results in the treatment and the prevention of cancer (Fujimiya et al., 1998; Mizuno et

\footnotetext{
1 Laboratory of Forest Resource Management, Division of Ecosphere Sciences and Management, Graduate School of Bioresource and Bioenvironmental Sciences, Kyushu University

* Corresponding author (E-mail: ohga@forest.kyushu-u. ac.jp)
}

al., 1998; Ebina and Fujiyama, 1998). The polysaccharides contained in this mushroom vitalized production of interferon and interleukin (Nakajima et al., 2002). In addition, many experiments proved that $A$. blazei could also prevent viruses and other external factors from entering the tissue (Nakajima, et al., 2002).

This mushroom is usually cultivated in naturally fermented substrates. The main substrate used in the cultivation of $A$. blazei are rice straw, wheat straw and sugar cane bagasse. However, we hypothesized that fermented livestock bedding materials as a substrate in the cultivation of this mushroom have endless possibilities. This substrate can be said to be economical and environmentally friendly, too.

Therefore, the conversion of cattle bedding compost into the biomedical fungus is a low cost initiative and an easily available substrate which can be a most profitable agri-business as it helps in its disposal in an environmentally friendly manner. To the best of our knowledge, beef cattle bedding compost has not yet been tested as a substrate for the cultivation of $A$. blazei. The aim of the study was to determine the effect of beef cattle bedding compost on the productivity of Agaricus blazei.

\section{MATERIALS AND METHODS}

\section{Microorganism}

The strain of Agaricus blazei Murrill KS-72 was used in the experiment which originated from Kyushu University. It was cultured on Potato Dextrose Agar (PDA) at $25^{\circ} \mathrm{C}$, and sub-cultured every three months.

\section{Source of compost}

One year fermented beef cattle bedding compost was used as a basal ingredient for substrate preparation. It was directly obtained from a local livestock company (Susuki Co. Ltd. Fukuoka, Japan). The Compost con- 
tained a mixture of chips from Cryptomeria japonica (L. f.) D. Don [Sugi], Picea glauca (Moench) Voss [White spruce, imported], Pseudotsuga menziesii (Mirb.) Franco [Douglas fir], Pinus thunbergii Parl. [Japanese black Pine], Pinus densiflora Sieb. \& Zucc. [Japanese red pine], Pinus ponderosa P. \& C. Lawson [Western yellow pine, imported], Tsuga sieboldii Carr. [Hemlock] and Abies firma Sieb. \& Zucc. [Momi fir]. The bedding had been about $10 \mathrm{~cm}$ thick in pens of beef cattle for a week. During the composting process, the material had been tilled once each month.

\section{Experimental preparation and conditions}

Collected cattle bedding compost was mixed with sawdust (Quercus sp) in the ratio of 25, 50, 75 and $100 \%$ (by weight) (compost/sawdust 1:3, 1:1, 3:1 and 1:0) and each mixture was supplemented by $20 \%$ (w/w) while 100\% was supplemented by equal ratio of supplement (1:1) and mixed thoroughly. A mixture of wheat, rice and barley bran was used as supplements. The completed substrates were adjusted to $65 \%$ moisture with tap water and the $\mathrm{pH}$ of substrate was measured and observed between pH 6.5 to 7.4. Seven hundred grams of wet substrate were placed in polypropylene bags (100g was set into the Petri dish for mycelial growth measurement) and sterilized at $121^{\circ} \mathrm{C}$ for $45 \mathrm{~min}$, then allowed to cool to the desired inoculation temperature and then 3\% sawdust spawn was inoculated (A $5 \mathrm{~mm}$ disc was inoculated for mycelium diameter measurement). The inoculated substrate was incubated at $25^{\circ} \mathrm{C}$ in darkness. Mycelial growth (diameter) was measured every week at intervals for three weeks.

After complete colonization, bags were cased with sterilized soil (2-2.5 cm, pH 6.5-7.5), and transferred into the mushroom house where the temperature was maintained at $23 \pm 1{ }^{\circ} \mathrm{C}$, the humidity was maintained at $90-95 \%, \mathrm{CO}_{2}$ concentration was maintained at $1000 \mathrm{ppm}$ by automatic aeration, and a light intensity of 500 lux was automatically changed from dark to light (12/12) by way of a fluorescent lamp. The data collection technique pertaining to colonization, primordial initiation, fruit body formation (day and yield), biological efficiency and mushroom size, as well as element analysis methods of substrate ingredients, were the same as the Pokhrel et al. (2006). pH and Ec were determined by using the HORIBA pH METER F-21 and CM-60V conductivity meter, respectively. Water holding capacity (WHC) was calculated from the following equation: $\mathrm{W}=$ (wet mass $\times 100 /$ dry mass). The results of various nutrients of substrate and supplements are presented in Table 1.

\section{RESULTS AND DISCUSSION}

\section{Effect on vegetative growth}

Weekly mycelial extension on differently mixed substrates is given in Table 2. Mycelial extension varied in different ratio of compost during incubation. The mycelial extension was significantly different in the substrate with different concentrations for one to three weeks of incubation. The substrate containing $75 \%$ compost was best for mycelial extension followed by 100, 50 and 25\%, respectively. Increasing the concentration of compost resulted better for mycelial extension. There are several factors which affect the vegetative growth and increasing concentration of compost showed better results for growth, and this could be due to high mineral nutrients, high moisture accumulation

Table 1. Nutrients contained in different substrate and supplements used

\begin{tabular}{cccccccc}
\hline & \multicolumn{7}{c}{ Nutrient elements (\%) } \\
\cline { 2 - 8 } Ingredients & $\mathrm{pH}$ & $\mathrm{Ec}$ & $\begin{array}{c}\text { Moisture } \\
\%\end{array}$ & $\begin{array}{c}\text { WHC } \\
\%\end{array}$ & $\mathrm{~N}$ & $\mathrm{~K}$ & $\mathrm{P}$ \\
\hline Substrates & & & & & & & \\
$\quad$ Compost & 8.3 & 0.658 & 46 & 262.9 & $1.9 \pm 0.1$ & 2.0 & 0.8 \\
Sawdust & - & - & - & - & $0.2 \pm 0.0$ & 0.2 & .1 \\
Supplements & & & - & - & $3.0 \pm 1.1$ & 0.1 & 0.3 \\
Barley bran & - & - & - & - & 2.1 & 1.6 & 1.6 \\
Rice bran & - & - & - & - & $2.3 \pm 0.4$ & 0.7 & 0.3 \\
Wheat bran & - & - & & - & - & - \\
Casing soil & 7.5 & 0.272 & 60 & 62.9 & - & - & - \\
\hline
\end{tabular}

Values are the mean \pm SD.

Table 2. Comparison of weekly mycelial extension of A. blazei on various concentrations of compost

\begin{tabular}{crcc}
\hline \multirow{3}{*}{$\begin{array}{c}\text { Nompost } \\
\%\end{array}$} & \multicolumn{1}{c}{1} & \multicolumn{1}{c}{2} \\
\cline { 2 - 4 } & $9.8 \pm 1.2$ & $23.2 \pm 3.2$ & $42.1 \pm 1.9$ \\
25 & $12.0 \pm 0.9$ & $33.2 \pm 1.0$ & $59.8 \pm 1.0$ \\
50 & $19.5 \pm 1.5$ & $58.9 \pm 1.3 \mathrm{a}$ & $79.2 \pm 1.6$ \\
75 & $14.9 \pm 1.7$ & $41.5 \pm 2.3$ & $73.8 \pm 1.3$ \\
\hline
\end{tabular}

Values are the mean \pm SD of mycelial growth measurement (mm). 
and rise in temperature inside the cattle bedding compost substrate during fungal growth. It is reported that mycelial growth was best at $69.9 \%$ moisture. Moreover, mycelial growth is very vigorous and fast, because it emits heat which is rather suitable in cattle compost. Therefore, increasing concentrations of compost promote the rate of mycelial growth.

\section{Effect on spawn run, primordial initiation and fruit body development}

Spawn run was completed when vigorous mycelial growth reached the surface. The result of time period to spawn run, primordial initiation and fruit body development are presented in Table 3. The most rapid spawn run (substrate colonization) took place in 38 days with $75 \%$ compost, which was the fastest among the different combinations used. It was followed by 41 days with $100 \%$ compost, and 44 days and 48 days with $50 \%$ and 25\% compost, respectively. Mycelial extension was positively correlated to spawn run, which corresponds with the result of day to primordial initiation and day to yield.

Table 3. Total day to spawn run, primordial initiation and fruit body development of $A$. blazei

\begin{tabular}{ccccc}
\hline $\begin{array}{c}\text { Compost } \\
\%\end{array}$ & $\begin{array}{c}\text { Spawn } \\
\text { run }\end{array}$ & $\begin{array}{c}\text { Primordial } \\
\text { initiation }\end{array}$ & $\begin{array}{c}\text { Fruit body } \\
\text { development }\end{array}$ & $\begin{array}{c}\text { Total day to } \\
\text { first crop }\end{array}$ \\
\hline 25 & 48 & 24 & 29 & 77 \\
50 & 44 & 19 & 23 & 67 \\
75 & 38 & 13 & 16 & 54 \\
100 & 41 & 14 & 18 & 59 \\
\hline
\end{tabular}

The results of primordial initiation and fruit body development (first crop) were recorded after the colonized bags were transferred into the growing house. Primordial initiation on compost containing $75 \%$ was observed at 13 days and a first crop was obtained at 16 days (Fig. 1). In the case of $100 \%$ compost, primordial initiation appeared on day 14 and first crop was obtained on day 18 (Fig. 2). Similarly, primordial initiation was recorded from $50 \%$ and $25 \%$ compost on day 19 and 24 , respectively, whereas first crop was obtained on days 23 and 29, in respective order. A higher concentra-

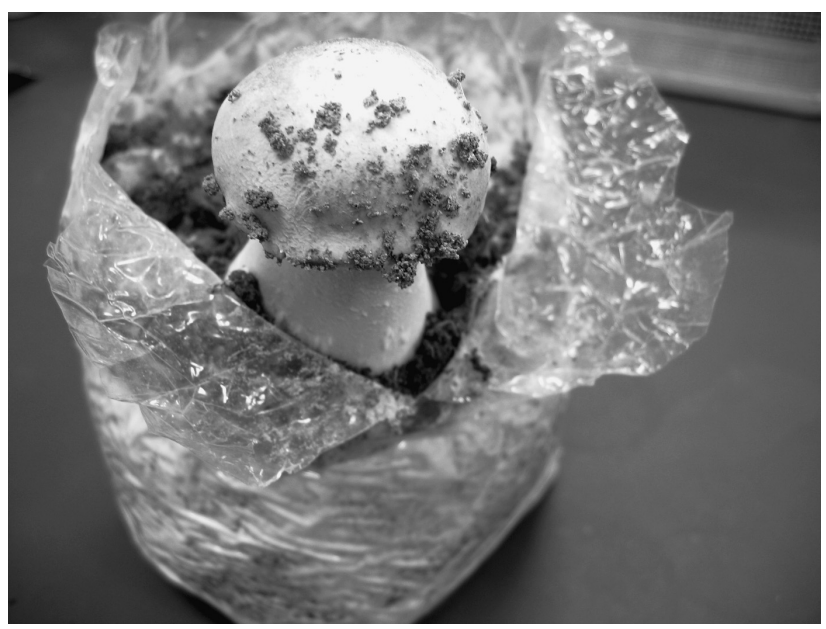

Fig. 1. Fruit body formation on $75 \%$ compost.

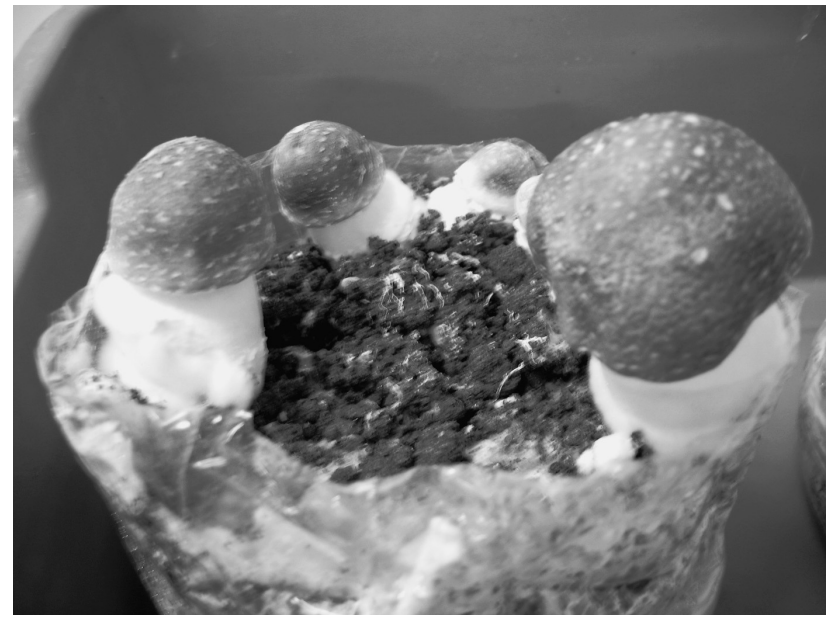

Fig. 2. Fruit body formation on $100 \%$ compost.

tion of compost (75\%) accelerates the mycelial extension and spawn run, primordial initiation and early fruiting; however, a higher concentration of supplement (100\% compost with equal supplement) activated a higher yield and an enhanced mushroom number. Supplements serve as nutrients to provide a more optimum growth medium (Royse, 1997). There were no significant differences in primordial initiation and fruiting period in between 75 and 100\% compost. Tan (1981) reported that Pleurotus osteratus and other species on cotton waste took 2-3 weeks for fruit body formation after spawn running, with a similar result also reported by Baysal et al. (2003) on oyster mushrooms. This study concluded that the first flush of mushrooms harvested from two to four weeks after transferred into mushroom house were better, which is consist with several reports.

\section{Effect on yields}

The effects of compost concentration on productivity were determined. Mushrooms were harvested before the pileus (cap) was fully extended. The button stage with intact veil membrane enclosing the gill is the most desirable stage. Average mushroom yield of two flushes from the four replicates are given in Table 4. The two flushes crops gave a maximum yield of $173.9 \mathrm{~g}$ on $100 \%$ compost followed by $155.4 \mathrm{~g}$ on $75 \%$ compost with a corresponding biological efficiency of $70.9 \%$ and $63.4 \%$, respectively. The lowest yield $70.0 \mathrm{~g}$ was obtained from $25 \%$, whereas moderate yield of $110.4 \mathrm{~g}$ on $50 \%$ compost with biological efficiency of 28.6 and 45.1, respectively. Compost with 100 and 75\% were superior to all the compost concentrations. Our results indicated that the addition of higher supplements increased the mushroom yield, whereas mushroom size was better from $75 \%$ compost. Furthermore, both higher amounts of compost and supplements are able to improve the growth and yield of this mushroom.

Slower mycelial extension, spawn running, fruit body formation and yield were observed where the concentration of compost was low. The first flush was observed between 54 to 77 days of cultivation. The second flush of mushrooms was obtained after a month 
Table 4. Cumulative mushroom yield (fresh wt. (g)/700 g wet substrate), biological efficiency and mushroom size of A. blazei on various concentrations of compost

\begin{tabular}{rcccccc}
\hline \multirow{2}{*}{$\begin{array}{c}\text { Compost } \\
\%\end{array}$} & \multicolumn{2}{c}{ Fresh weight of mushrooms by flushes (g) } & \multirow{2}{*}{$\begin{array}{c}\text { BE } \\
\text { First }\end{array}$} & Second & $\begin{array}{c}\text { Total fresh } \\
\text { weight (g) }\end{array}$ & $\begin{array}{c}\text { Size } \\
\text { g/mushroom }\end{array}$ \\
\cline { 2 - 4 } 25 & $30.9 \pm 4.0$ & $39.1 \pm 9.2$ & $70.0 \pm 8.6$ & 28.6 & $30.1 \pm 1.3$ \\
50 & $39.9 \pm 12.6$ & $70.5 \pm 9.1$ & $110.4 \pm 5.6$ & 45.1 & $41.1 \pm 1.7$ \\
75 & $75.5 \pm 3.6$ & $79.9 \pm 5.4$ & $155.4 \pm 8.3$ & 63.4 & $59.3 \pm 18.6$ \\
100 & $110.5 \pm 7.1$ & $63.4 \pm 6.0$ & $173.9 \pm 11.5$ & 70.9 & $34.26 \pm 3.6$ \\
\hline
\end{tabular}

Values are the mean \pm SD.

of first flush. Interestingly, the maximum yield was harvested during the first flush (about double) when compost was enriched with higher amounts of supplements. This result is not consist with reports from Stamets, (2000). Likewise, more or less equal mushroom yield was obtained from both flushes with 75\% compost, whereas a higher amount of yield was harvested in the second flush with 50\% and 25\% compost in the respective order. This lower concentration of compost to the substrate significantly decreased mushroom yield probably due to the low nutrient content in substrate. Therefore, fresh sawdust or non-fermented substrates are not very appropriate in the cultivation of this fungus, as it cannot easily degrade complex lignocelluloses components. The increasing concentration of cattle bedding compost is better for its growth, and development showed that this fungus easily thrives on sole cattle bedding compost. Generally, higher concentrations of livestock manure did not produce better results due to the presence of elevated nitrogen concentrations already present in it, but this statement did not apply to this mushroom. Our result was not consistent with the result of Baysal, et al. (2003) and Laborde et al. (1984). The selection of substrate for the cultivation of mushroom is largely determined by the abundance and cost of the substrate. Two factors are required of substrate for economic mushroom production: low cost and good yield (Pokhrel et al., 2006). Thus, the substrate used in the experiment was made relatively economically and was an easily available material. The yield with the 100 and $75 \%$ compost were quite acceptable.

\section{CONCLUSIONS}

In conclusion, $A$. blazei, a choice edible mushroom of biomedical importance, is a second stage decomposer with simple carbohydrate metabolism. It grows in soil rich in lignicolous debris, in mixed woods, well-composted soil, and along forest edges. This mushroom is a complex saprophyte and prefers composting soil rich in plant debris. It also grows in well-manured grasslands. Cultivation of this species, primarly based on fermented compost. In this study, we successfully found a great possibility for its cultivation in beef cattle bedding compost-a refractory waste, with massive potential.

Appropriate concentration and supplements can enhance mushroom quality and yield while creating a shorter production time. High compost concentration gave us better results for mycelial extension and spawn run, earlier primodial initiation and fruit body development with bigger sized mushrooms; however, a higher percentage of supplement stimulated higher yield and number of fruit bodies.

\section{REFERENCES}

Baysal, E., H. Peker, M. K. Yalinkilic and A. Temiz 2003 Cultivation of Oyster mushroom on waste paper with some added supplementary materials. Bioresour. Technol., 89 : 95-97

Ebina, T. and Y. Fujiyama 1998 Antitumor effect of peptide-glucan preparation extracted from agaricus from Agaricus blazei Murill in a double grafted tumor system in mice. Biotherapy, 11: 259-265

Fujimiya, Y., Y. Susuki, K. Oshiman, H. Kobori, K. Moriguchi, H. Nakashima, Y. Matumoto, S. Takahara, T. Ebina and R. Katakura 1998 Selective tumoricidial effect of soluble proteglucane extracted from the basidiomycete, A. blazei Murill, mediated via natural killer cell activation and apoptosis. Cancer Immunol. Immunother., 46: 147-159

Kawagishi, H., R. Katsumi, T. Sazawal, T. Mizuno, T. Hagiwari and T. Nakamura 1998 Cytotoxic steroids from the mushroom Agaricus blazei. Phytochem., 27: 2777-2779

Kuroiwa, Y., A. Nishikawa, T. Imazawa, K. Kanki, Y. Kitamura, T. Umemura and M. Hirose 2005 Lack of subchronic toxicity of an aqueous extract of Agaricus blazei Murill in F344 rats. Food Chem. Technol., 43: 1047-1053

Laborde, J., P. Clauzel, O. Crabos and J. Delmas 1984 Aspects pratoques de la culture de Pleurotous sp. In: Proceeding of the International Symposium on substrate for Mushrooms growing and Cultivation of Pleurotus Species. Part II. pp 66-97

Mizuno, M., M. Morimoto, K. Minato and H. Tschida 1998 Polysaccharides from Agaricus blaezi stimulate lymphocyte T-cell subsets in mice. Biosci. Biotechnol. and Biochem., 62: $434-437$

Nakajima, A., T. Ishida, M. Koga, T. Takeuchi, O. Mazda and M. Takeuchi 2002 Effect of hot water extract from Agaricus blazei Murill on antibody-producing cell in mice. Int. Immunpharmacol., 2: 1205-1211

Pokhrel, C. P., Sumikawa, S. Iida, S and S. Ohga 2006 Growth and Productivity of Lyophyllum decastes on compost enriched with various supplements. Mycologia Appl. Int., 18: 21-28

Royse, D. J. 1997 Specialty mushrooms and their cultivation. Hortic. Rev., 19: 59-97

Stamets, P. 2000 Growing Gourmet and Medicinal Mushroom. The speed press, Third edition pp 208-216

Tan, K. K. 1981 Cotton waste as a good substrate for cultivation of (Pleurotus osteratus). The Oyster mushroom. Mush. Sci., 11: 705-710 